\title{
Linking service convenience to satisfaction: Dimensions and key moderators
}

\author{
Sabine Benoit, ${ }^{1}$ Sonja Klose ${ }^{2}$ \& Andreas Ettinger ${ }^{3}$
}

Keywords: Service convenience, retailing, shopping, customer characteristics, partial least squares

\footnotetext{
${ }^{1}$ Dr. Sabine Benoit, Professor of Marketing, Surrey Business School, University of Surrey, Guildford, GU2 7XH, United Kingdom, s.benoit@surrey.ac.uk

2 Dr. Sonja Klose, Lecturer, FOM University, 10625 Berlin, Germany, sonja.klose2@,fom-net.de

${ }^{3}$ Dr. Andreas Ettinger, Senior Manager Database Marketing, Unitymedia Kabel BW GmbH, Cologne, Germany, andreas_ettinger@msn.com
} 


\section{Linking service convenience to satisfaction: Dimensions and key moderators}

\section{Structured abstract:}

Purpose: Demand for service convenience, defined as a consumer's perception of minimized time and effort spent to obtain a service, has increased in conjunction with certain sociocultural and demographic changes. Prior research notes the significance of service convenience, but the importance of different dimensions of service convenience as well as the role of key moderators affecting the link between convenience and satisfaction (like customer psychographic and sociodemographic characteristics) remain unaddressed.

Design/methodology/approach: Two models are developed and tested: 1) a multidimensional model of service convenience with a formative measure of five service convenience dimensions: decision, access, search, transaction, and after-sales convenience; and 2) a moderator model hypothesizing different customer psychographic and sociodemographic characteristics (time pressure, shopping enjoyment, age, household size, income) that affect the link between service convenience and satisfaction.

Findings: This study reveals that search convenience, followed by transaction and decision convenience, exerts the greatest influence on the perception of overall service convenience. In addition, those who value service convenience most are high-income, time-pressed consumers in smaller households who experience low shopping enjoyment.

Originality/value: Providers have limited budgets for enhancing their services. Thus it is important to identify which dimension has the greatest influence on the perception of service convenience as well as the customer segments for which service convenience is most critical. 


\section{INTRODUCTION}

In his recent Journal of Services Marketing article "Revisiting 'big ideas in services marketing' 30 years later," Leonard L. Berry states, "The pervasive influence of the Internet on customers' rising convenience expectations cannot be overestimated. What used to be fast is now slow" (Berry, 2016). Offering service convenience, defined as a consumer's perception of minimized time and effort to obtain a service (Berry et al., 2002), has become crucial to be competitive. Changing sociocultural and sociodemographic characteristics of consumers further fuel the demand for service convenience (Berry, 1979; Seiders et al., 2007).

This demand for service convenience is highly relevant for service providers: It influences which service firms consumers choose to (re)patronize, as well as their perceptions of the service experience. It contributes to customers' experience along with their sense of satisfaction, and therefore represents a key research priority (Ostrom et al., 2015). Prior research has shown (Andaleeb and Basu, 1994) or assumes (Berry, 2016) that service convenience has a positive impact on the perception of the service experience and drives customer satisfaction. Customer satisfaction then leads to long-term benefits, including customer loyalty and increased profitability (Cooil et al., 2007; Homburg et al., 2005). Although prior research has established the positive effects of the dimensions of service convenience and service convenience itself, important issues have gone unaddressed.

First, service convenience was introduced theoretically as a multidimensional construct (Seiders, et al., 2000) encompassing the dimensions of decision, access, transaction, benefit, and post-benefit convenience (Berry et al., 2002). Subsequently, service convenience dimensions have been shown to influence such outcome variables as satisfaction, repurchase visits/spending, and referral (see Seiders et al., 2005; Seiders et al., 2007), repurchase intentions in an online 
shopping context (Jiang et al., 2013), share of wallet, share of visits, and exit intention (Moeller et al., 2009), and loyalty (Kaura et al., 2015). We too consider service convenience as a multidimensional construct, and contribute to the literature by testing how these individual convenience dimensions contribute to the overall perception of service convenience. Considering the need for concise questionnaires, we designed a short scale for the overall construct with four items that capture $2 / 3$ of the variance of the multidimensional measurement with over 20 items. Our research reveals which dimensions are most important to the perception of service convenience and should thus be prioritized from a managerial perspective.

Second, the conceptual literature on service convenience assumes that the relationship between service convenience and customer satisfaction is moderated by customer characteristics (Berry et al., 2002). Empirical research has not tested this, however, nor identified which customer psychographic and sociodemographic characteristics might be significant. Our study provides empirical results that document how customer characteristics like time pressure, shopping enjoyment, age, household size, and income affect the link between a major consumer trend (service convenience) and a major driver of profitability (satisfaction) (Cooil et al., 2007; Homburg et al., 2005). These results reveal which customer groups service providers should target to maximize their impact.

Both contributions, the dimensions model and the moderator model, are particularly effective because convenience is a context-dependent construct (Jiang et al., 2013). In the next section, we introduce the multidimensional concept of service convenience, define its dimensions, introduce existing measurement approaches, and explain our approach to creating the dimensions model (see Figure 1). Afterwards, we review the literature on service convenience and deduce the moderator model (see Figure 2), starting with the baseline hypothesis that service convenience 
has a positive effect on satisfaction. We then explore the moderating hypotheses that psychographic variables - like time pressure and shopping enjoyment along with such demographic variables as age, household size, and income - all have an impact on the relationship between service convenience and customer satisfaction. In the subsequent section we describe how both of these models have been tested. Finally, we discuss the theoretical and managerial implications of our results, provide limitations, and recommend directions for future research.

\section{FRAMEWORK AND HYPOTHESES}

Service convenience is a consumer's perception of the degree to which he or she can avoid spending the time and effort associated with shopping (Berry et al., 2002). Previous studies have proposed that service convenience is a multidimensional construct (Berry et al., 2002; Seiders et al., 2005, 2007; Colwell et al., 2008; Jiang et al., 2013; Moeller et al., 2009). In our dimensions model (Figure 1), we adopt this view and investigate the significance of each dimension of service convenience towards an overall one-dimensional service convenience construct. Our second model utilized this overall one-dimensional service convenience construct and examines the moderating effects of customer demographics on the convenience-satisfaction link (Figure 2). The use of the one-dimensional construct is justified for two reasons: First, we believe that a one-dimensional service convenience construct (with four items rather than around 20) will enable more researchers to include service convenience in their work; and second, we show empirically that our one-dimensional conceptualization accurately represents a multidimensional one, as explained in the methods section.

\section{Conceptualization of Service Convenience}


The following dimensions have been proposed for service convenience: decision, access, search, transaction, and after-sales convenience (Berry et al., 2002; Seiders et al., 2005, 2007; Colwell et al., 2008; Jiang et al., 2013; Moeller et al., 2009). In our dimensions model (Figure 1) we adopt this conceptualization.

Decision convenience refers to the consumer's perception of minimal time and effort required to decide to patronize the service provider, which is mainly determined by the availability and quality of information (Seiders et al., 2007). Access convenience reflects the consumer's perception of minimal time and effort needed to reach the service provider's location, which usually is a function of its physical location, parking availability, and operating hours (Jones et al., 2000; Seiders et al., 2000). Search convenience captures the consumer's perception of the time and effort required to identify and select products he or she wishes to buy (Dabholkar et al., 1996). Transaction convenience means the minimized time and effort necessary to complete the transaction, including the ease and speed with which the consumer can find the checkout area and move through it (Dabholkar et al., 1996). Finally, after-sales convenience involves the consumer's perception of minimal time and effort in any customer activity after purchase, such as returning merchandise, levying complaints, or obtaining a guarantee (Seiders et al., 2000).

Service convenience dimensions have been operationalized as reflective (Seiders et al., 2005, 2007, Jiang et al., 2013) as well as formative (Moeller et al., 2009). We adopt the formative operationalization, in keeping with Moeller et al. (2009), and further operationalize service convenience and thus our dimensions model (Figure 1) as a MIMIC model—meaning that the construct is measured redundantly by measuring the first order dimensions are formative, whereas the second order factor is reflective (Diamantopoulos et al., 2008). Following the logic 
of second-order models, with dimensions being part of the construct, we do not formulate hypotheses for this model.

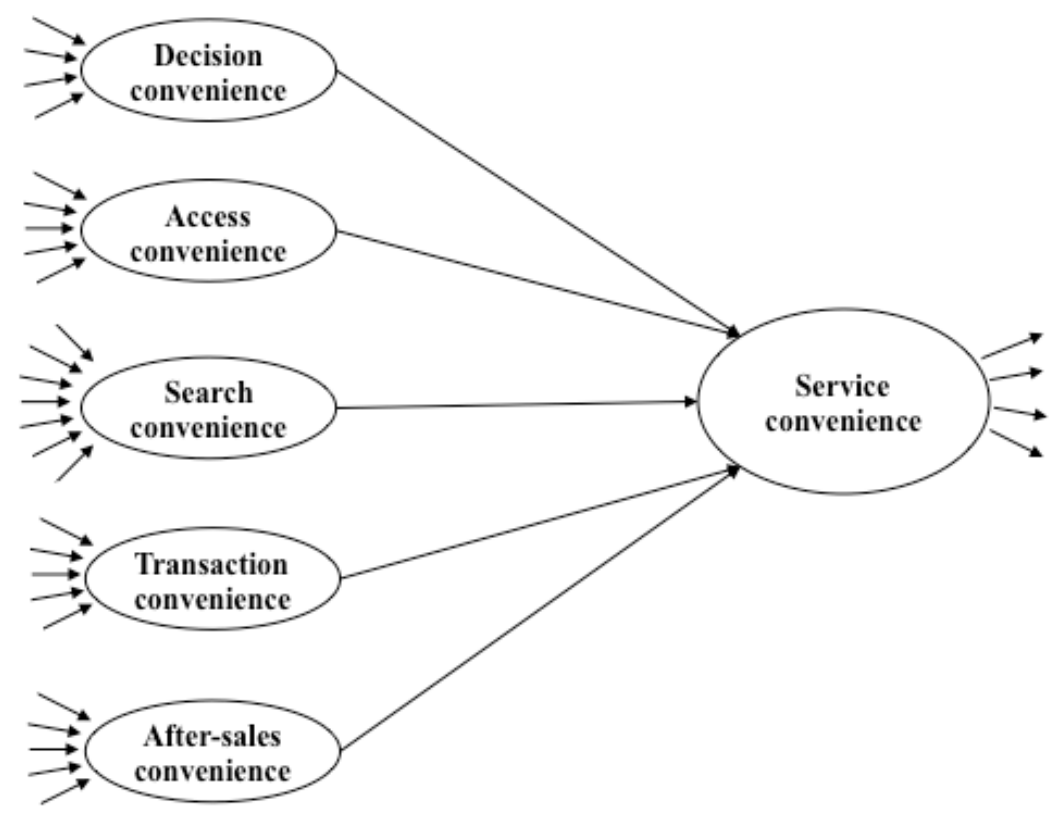

Figure 1: Service convenience dimensions (dimensions model)

The Link between Convenience and Satisfaction

Studies show that consumers' perceived minimization of nonmonetary expenditures in terms of time and effort (convenience) positively influences their satisfaction (Andaleeb and Basu, 1994; Kaura et al., 2014). Two conceptualizations of customer satisfaction have evolved: transaction-specific and cumulative (Olsen and Johnson, 2003). The transaction-specific perspective regards customer satisfaction as a post-choice evaluation of a specific purchase occasion (Anderson et al., 1994), whereas cumulative customer satisfaction refers to a global evaluation based on experience with the provider over time (Homburg et al., 2005). We examine cumulative customer satisfaction.

Customers evaluate their relationships to companies by comparing experienced outcomes with their initial expectations. Expectations as well as outcomes relate to the input-output ratio of 
these relationships. According to social exchange theory (Thibaut and Kelley, 1959) and equity theory (Adams, 1965), individuals are satisfied with relationships and deem those relationships fair if they feel their input is in due proportion to the output they receive. These theoretical approaches consider the importance of a given (customer's) input rather than focusing solely on a given output (i.e., company performance). To create satisfying customer relationships, service providers therefore have two possibilities: enhancing output or minimizing customer input, including monetary as well as nonmonetary costs.

A minimization of these nonmonetary costs should positively influence value perceptions of a service (Berry, 2016; Berry et al., 2002; Pan and Zinkhan, 2006). Therefore, as our foundational hypothesis for our moderator model, we posit:

H1: Service convenience positively influences customer satisfaction.

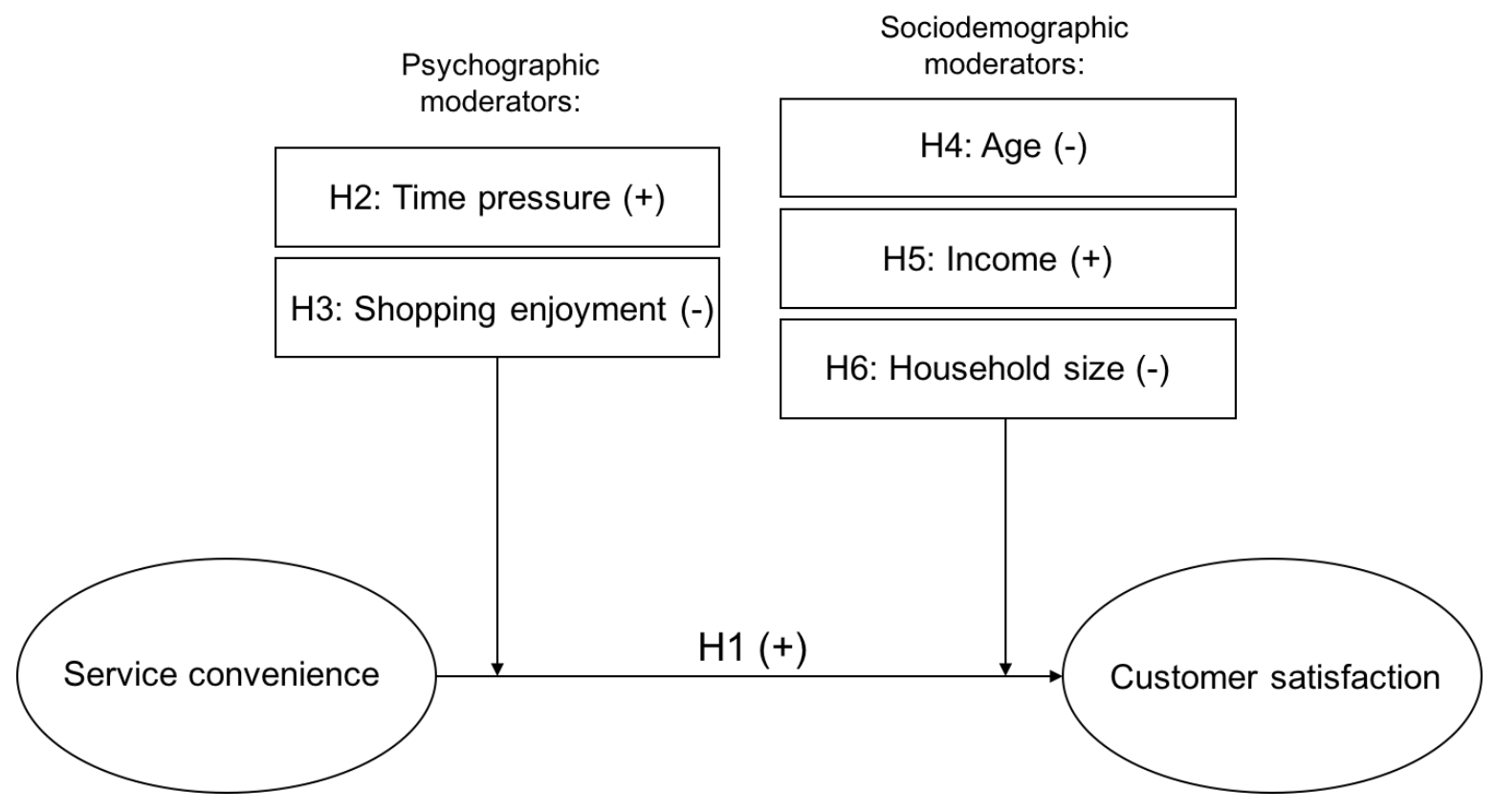

Figure 2: Framework and hypothesized effects (moderator model)

Moderators of the Service Convenience-Customer Satisfaction Relationship 
Customer characteristics describe the time and effort available for shopping (Becker, 1965; Marmorstein and Grewal, 1992). Each consumer values time and effort costs differently: The higher a consumer's valuation of these scarce resources, the greater the influence of service convenience on customer satisfaction. We investigate two psychographic and three sociodemographic customer characteristics. The psychographic characteristics are time pressure and shopping enjoyment; the sociodemographic are age, income, and household size. Prior research has shown that each of these characteristics affects consumers' available time and effort (Hornik, 1982) and so should be connected to perceptions of service convenience.

Time pressure. Time pressure is "the perceived constriction of the time available for an individual to perform a given task" (Iyer, 1989, p. 43). Existing studies investigate the effects of time pressure on shopping behavior and the choice of outlets, concluding that time-pressured consumers are more likely to visit service providers that help them save time and effort (Ackerman and Gross, 2003; van Kenhove and de Wulf, 2000; Lloyd et al., 2014). Wait-time research confirms that time-pressured consumers tend to avoid service providers that they anticipate will require a longer wait (Grewal et al., 2003) and express higher satisfaction in response to a short waiting time (Davis and Vollmann, 1990). In our study, time pressure refers to the perceived constraints on time available for shopping. Consumers experiencing time pressure believe that they lack the time necessary to accomplish their shopping and feel hurried or rushed. The impact of service convenience on customer satisfaction therefore should increase with perceived time pressure, such that

H2: Time pressure positively moderates the relationship between service convenience and customer satisfaction. 
Shopping enjoyment. Regarding shopping enjoyment, or "the pleasure one obtains in the shopping process" (Beatty and Ferrell, 1998, p. 174), the existing literature usually distinguishes recreational from economic shoppers (Dawson et al., 1990; Williams et al., 1985). Recreational shoppers enjoy shopping as a leisure activity, from which they derive emotional benefits and pleasure (Babin et al., 1994; Reynolds and Beatty, 1999). In contrast, economic shoppers dislike shopping or are neutral toward it, because they do not perceive many benefits of it. They avoid shopping or attempt to minimize the time and effort spent engaging in it (Babin et al., 1994). In addition to the type of shopper, the retail context influences the probability of economic versus recreational shopping; for example, grocery shopping is considered as economic (Kaltcheva and Weitz, 2006). Previous studies indicate that recreational shoppers who enjoy the activity are more likely to spend time and effort shopping than economic consumers with low shopping enjoyment (Beatty and Ferrell, 1998). It seems reasonable to assert that the influence of service convenience on customer satisfaction is greater when the customer's shopping enjoyment is lower. Thus, we hypothesize:

\section{H3: Shopping enjoyment negatively moderates the relationship between service} convenience and customer satisfaction.

Age. Older consumers generally have more free time and can allocate more time to shopping (Ailawadi et al., 2001; East et al., 1998). In contrast, most young adult consumers must allocate their available time and effort budgets across both work and household demands (Gross, 1987). Consequently, younger customers experience greater time pressures and are more likely to visit providers that help them save time and effort (McDonald, 1994). Therefore, we expect that the impact of service convenience on customer satisfaction decreases with age and hypothesize: 
H4: Age negatively moderates the relationship between service convenience and customer satisfaction.

Income. From an economic perspective, time spent shopping can be expressed in monetary terms as opportunity costs (Becker, 1965), often in terms of the consumer's income (Leclerc and Schmitt, 1995; Okada and Hoch, 2004). The opportunity costs for shopping therefore should increase with income, such that higher-income customers value their time more and are more discriminating in how they allocate it (Lloyd et al., 2014; Marmorstein and Grewal, 1992). We posit that the influence of service convenience on customer satisfaction increases with the consumer's income and hypothesize:

H5: Income positively moderates the relationship between service convenience and customer satisfaction.

Household size. Finally, existing studies reveal that single-person households are more convenience-oriented than multiple-person households (Candel, 2001; Scholderer and Grunert, 2005). Singles can thus be expected to visit providers that help them save time and effort so as to stretch their available time and effort budgets across both work and household demands (Gross, 1987). Larger households have more flexibility allocating their shopping activities to different members of the household; one person in a larger household can address the needs of the other members, especially for items like groceries and packaged goods. The influence of service convenience on customer satisfaction should therefore decrease with household size. We hypothesize:

H6: Household size negatively moderates the relationship between service convenience and customer satisfaction. 


\section{EMPIRICAL STUDY}

\section{Data Collection}

To collect our data and test both models we collaborated with a retailer in the consumer and packaged goods sector. This is an appropriate research setting for three reasons. First, grocery and packaged goods consumers are economically oriented and price sensitive (Govers and Schoormans, 2005), so convenience should be very relevant. Second, the groceries and packaged goods sector constitutes one of the largest and most important shopping contexts. Third, in-store shoppers in the grocery context do not behave differently from those who shop online in terms of time spent or effort expended (Jiang et al., 2013).

We collected data through a nationwide mail survey of customers of a Western European retailer. The retailer provided contact information for 4,500 cardholders of a nationwide loyalty program that features more than 25 varied companies, including our focal grocery and packaged goods retailer. In this country, more than $60 \%$ of the households possess such a loyalty card, so we can assume that we captured a high proportion of the provider's transactions with this population. We randomly selected customers who had purchased from any store in the preceding eight weeks, but also ensured that respondents with low, medium, and high shopping expenditures and frequency appeared in the sample. In addition, because some respondents might lack experience with after-sales services, we designed the survey to include a "no experience" response for the five after-sales convenience items.

We pre-tested the questionnaire with 20 potential respondents from the same sample population, following Dillmann's (2000) recommendations. This pre-test resulted in minor modifications in the wording of some items. To increase response rates in the main study, we provided a personally signed letter with a pre-addressed, postage-paid return envelope as well as 
a $20 €$ coupon offered as an incentive. After six weeks, we sent a follow-up letter and survey to non-respondents, offering them another chance to participate. A total of 1,036 people responded, for an effective response rate of $23 \%$. After screening the questionnaires for completeness, we obtained a total of 972 usable responses.

We found no significant differences between early and late responses, meaning that nonresponse bias did not appear to be an issue (Armstrong and Overton, 1977). We also compared our sample against nationwide demographic variables of grocery shoppers. According to AC Nielsen (2015) our sample is representative of customers of grocery and packaged goods retailers. Furthermore, we conducted a missing data analysis using SPSS; the small amounts of missing data appeared random and thus could be imputed by means of the EM algorithm available in SPSS (Schafer and Graham, 2002).

\section{Measures}

We drew the scales for customer satisfaction, time pressure, and shopping enjoyment from previous research. The cumulative customer satisfaction variable consisted of three items adapted from Voss et al. (1998). To measure the moderating variables of time pressure and shopping enjoyment, we used three items from Putrevu and Ratchford (1997) and Urbany et al. (1996), adapted to the packaged goods context. The items all used seven-point Likert scales ranging from "strongly agree" (1) to "strongly disagree" (7). For the sociodemographic moderating variables (age, income, household size), we used self-reported measures with five or six categories each.

For service convenience, our focal variable, we drew on existing scales from Moeller et al. (2009) to measure the dimensions of service convenience within the dimensions model (Figure 1). The existing literature conceptualizes service convenience as a multidimensional construct 
with five first-order factors (Seiders et al., 2007). Our research contributes to the literature by testing how these individual dimensions contribute to the overall perception of service convenience. We note that each dimension of service convenience includes many different aspects that together constitute the formative construct (Coltman et al. 2008; Jarvis et al., 2003). For example, access convenience includes both time-related accessibility in terms of operating hours, and space-related accessibility in terms of location and parking spaces. Search convenience includes the orientation in the store, its atmosphere, product locations, and the ease of product decisions. Even transaction convenience features checkout personnel, payment methods, and waiting time at the cashier (see Appendix 1). We operationalize service convenience as a MIMIC model—meaning that the construct is measured redundantly by measuring the first order dimensions as formative, whereas the second order factor is measured reflectively (Diamantopoulos et al., 2008).

To measure the overall perception of service convenience within the moderator model, we developed a new one-dimensional scale to offer a short version of a service convenience scale. This compact scale should enable more researchers to integrate this important construct into their models. This new four-item measure captures $2 / 3$ of the multidimensional construct measured by 26 items and is thus a good representation of the overall concept.

\section{ANALYSIS AND RESULTS}

\section{Validity and Reliability}

To assess the validity and reliability of our measures, we used different evaluative criteria for the constructs with formative indicators (service convenience dimensions) and reflective 
indicators (overall service convenience, customer satisfaction, time pressure, and shopping enjoyment, see Appendix 1 and 2).

To evaluate the validity and reliability of the formative second-order service convenience construct, we followed criteria specified by Diamantopoulos and Winklhofer (2001) and MacKenzie et al. (2005): (1) content specification; (2) indicator specification; (3) multicollinearity test; (4) discriminant validity, and (5) external validity. These five criteria confirmed that our formative measures are valid and reliable. As we show in Appendix 1, for all indicators, the $\mathrm{p}_{\mathrm{sa}}$ and $\mathrm{c}_{\mathrm{sv}}$ were well above the cut-off values of $.50\left(\mathrm{p}_{\mathrm{sa}}\right)$ and $0\left(\mathrm{c}_{\mathrm{sv}}\right)(\mathrm{J} . \mathrm{C}$. Anderson and Gerbing, 1991).

Second, indicator specification relates to the relevance of each indicator in creating the formative construct (Chin, 1998), as represented by the significance weights of the formative indicators, which were sufficient for 21 of the 26 formative indicators (see Appendix 1). Weights (formative indicators) should not be interpreted as factor loadings (reflective indicators), however, so we did not need to eliminate the five formative indicators with insignificant weights, as we would have done for reflective indicators (Bollen and Lennox, 1991).

Third, in formative measurement models, eliminating indicators is appropriate only if two items capture similar aspects and thus exhibit multicollinearity (Diamantopoulos and Winklhofer, 2001). In our study, the highest variance inflation factor (VIF) was 3.626, and most (24 of 26) indicators revealed VIFs far below 3 (see Appendix 1). Given that researchers consider VIFs up to 10 acceptable (Hair et al. 2006), we found no evidence of multicollinearity.

Fourth, MacKenzie et al. (2005) suggest testing for discriminant validity of formative constructs. Correlations of less than .71 would indicate the service convenience dimensions had good discriminant validity, such that all five dimensions represented distinct areas of service 
convenience (Bruhn, et al., 2008). The significant path coefficients between the dimensions and the overall service convenience construct confirmed the discriminant validity of our measures.

Fifth and finally, internal consistency examinations are inappropriate for formative constructs, so their external validity should be tested (e.g., Jarvis et al., 2003). One approach is to measure the construct in question as a reflective construct. Because we developed a new scale for the perception of service convenience in the moderator model, we assume external validity for service convenience. This measure was satisfactory (Appendix 1). In keeping with prior research (e.g., Jarvis et al., 2003), we assessed external validity at the indicator and dimension levels by correlating each indicator of the five first-order dimensions (26) with the reflective global service convenience measure. All correlations were significant, affirming external validity (see Appendix 1). The results in Appendix 1 further detail our formative measures of the service convenience dimensions. Weights represent the importance of each indicator for the construct. For example, for search convenience, the two most important indicators were orientation in the store and easy selection of merchandise. We therefore can derive implications for both researchers and managers.

We tested the validity and reliability of all reflective constructs (service convenience, customer satisfaction, time pressure, and shopping enjoyment), using the criteria proposed by Chin (1998) and Hulland (1999), namely, indicator reliability (factor loadings $>.70$, t-values > 1.645), convergent validity (Cronbach's alpha $>.70$, composite reliability $>.60$ ), and average variance extracted $(\mathrm{AVE}>.50)$. All criteria exceeded the cut-off values (Appendix 2) and therefore indicated high levels of convergent validity. In addition, we assessed discriminant validity using Fornell and Larcker's (1981) criterion and cross-loadings. None of the intercorrelations of the construct exceeded the square root of the AVE, and no item cross-loaded 
higher on another construct than on its associated construct (Chin, 1998); therefore, the constructs exhibited satisfactory discriminant validity.

\section{Dimensions Model}

As recommended by Chin et al. (2003), we used partial least squares (PLS-Graph 3.0; Wold, 1966) to estimate the effects of the dimensions in our model 1 and the moderating effects in model 2. As Chin (1998) notes, PLS path modeling is very appropriate for models that contain formative constructs. We first tested the impact of the dimensions on the overall service convenience construct. First, all paths were significant $(\mathrm{p}<.01)$, and four out of five were greater than the critical value of .10 (Lohmöller, 1989). Search convenience (.42) has by far the highest impact; transaction (.22) and decision convenience (.20) have a medium impact, and access (.10) and after-sales convenience (.07) have the lowest impact. We further tested model fit according to Cohen's (1988) classification, and found that the overall service convenience construct $\left(\mathrm{R}^{2}=\right.$ .66) has true explanatory power. This proves the quality of our new reflective scale of overall service convenience.

The weights of an indicator in Appendix 1 represent its importance in forming the dimension (Chin, 1998). From our results we can conclude that well-trained checkout clerks (.482) are more important to the perception of transaction convenience than the atmosphere in the sales area (.298). To avoid redundancy we will elaborate on these results in the implication section.

\section{Moderator Model}

To test the hypotheses in our moderator model, we employed the two-step score construction procedure (Chin et al., 2003, Supplement A). The PLS method supports the explicit estimation of latent variable scores, after standardizing the latent variable scores (Tenenhaus et al., 2005). We calculated the interaction terms and included them in the model so that we could test for a 
relatively large number of moderating effects while correcting for measurement error (Chin et al., 2003). We used a bootstrapping procedure with 500 replications to test the effects and statistical significance of the parameters in the structural model (Chin, 1998; Chin, 2001). For the moderator model recommended by Chin et al. (2003), we used a hierarchical approach to test our hypotheses, such that we first estimated a model with only main effects and then added the moderating effects, as detailed in Table 1.

Table 1

Hypothesis tests, moderator model

\begin{tabular}{lllll} 
Hypothesis & Relationship & $\begin{array}{l}\text { Hypothesized } \\
\text { Direction }\end{array}$ & Path Coefficient $\boldsymbol{\beta}$ & Results \\
\hline $\mathrm{H} 1$ & $\mathrm{SCON} \rightarrow \mathrm{SAT}$ & Positive & $.77^{* *}$ & Supported \\
$\mathrm{H} 2$ & $\mathrm{SCON}{ }^{*} \mathrm{TP} \rightarrow \mathrm{SAT}$ & Positive & $.16^{*}$ & Supported \\
$\mathrm{H} 3$ & $\mathrm{SCON}{ }^{*} \mathrm{SE} \rightarrow \mathrm{SAT}$ & Negative & $-.26^{* *}$ & Supported \\
$\mathrm{H} 4$ & $\mathrm{SCON}{ }^{*} \mathrm{AGE} \rightarrow \mathrm{SAT}$ & Negative & .13 & Not supported \\
$\mathrm{H} 5$ & $\mathrm{SCON}^{*} \mathrm{INC} \rightarrow \mathrm{SAT}$ & Positive & $.34 * *$ & Supported \\
$\mathrm{H} 6$ & $\mathrm{SCON}{ }^{*} \mathrm{HHS} \rightarrow \mathrm{SAT}$ & Negative & $-.22^{*}$ & Supported \\
\hline Fit Measures & & & Main Effect Model & Final Model \\
\hline $\mathrm{R}^{2}$ & & & .59 & .64 \\
$\mathrm{Q}^{2}$ & & & .08 & .11 \\
\hline
\end{tabular}

Notes: $\mathrm{SCON}=$ service convenience; $\mathrm{SAT}=$ customer satisfaction; $\mathrm{TP}=$ time pressure; $\mathrm{SE}=$ shopping enjoyment; $\mathrm{AGE}=$ age; INC = income; HHS = household size. Significance based on one-tailed-test.

$* p<.05 ; * * p<.01 ;$ coefficients in italics are not significant.

In support of H1, we found a significant direct, positive effect of service convenience on customer satisfaction $(\beta=.77)$. Service providers can enhance their customers' satisfaction by increasing service convenience. We also found significant moderating effects for all our predictions, with the exception of the age effect. Specifically, the impact of service convenience on customer satisfaction was stronger when time pressure $(\beta=.16)$ and income $(\beta=.34)$ 
increased, in support of $\mathrm{H} 2$ and $\mathrm{H} 5$, respectively. The link between convenience and satisfaction weakened with greater shopping enjoyment $(\mathrm{H} 3, \beta=-.26)$ and a larger household size (H6, $\beta=$ .22). The lack of support for the expected moderating effect of age (H4) implied that the impact of service convenience on customer satisfaction was equally strong for older and younger customers. We elaborate on these results in the discussion section.

\section{Model Fit}

To evaluate the fit of the moderator model we followed Chin's (1998) recommendations and applied $\mathrm{R}^{2}$ and the Stone Geisser test $\left(\mathrm{Q}^{2}\right)$. The $\mathrm{R}^{2}$ value represents the explanatory power of structural models (Fornell and Cha, 1994). According to the categorization by Cohen (1988), the explanatory power of our moderator model is large $\left(\mathrm{R}^{2}=.64\right.$, Table 1$)$. Furthermore, $\mathrm{Q}^{2}(=.09)$ is greater than 0 , in support of the predictive relevance of the moderator model (Fornell and Cha, 1994). The $\mathrm{R}^{2}$ for the model that includes both main and interaction effects was .64 , and that for the main effects model was .59. According to an incremental F-test $(F=19.3)$, the $\Delta R^{2}$ was statistically significant. We calculated $\mathrm{f}^{2}$ to assess the effect size of the interaction terms in the moderator model; the $\mathrm{f}^{2}$ values between .02 and .05 suggested small to moderate effect sizes (Cohen, 1988).

\section{IMPLICATIONS}

We have identified two gaps in prior research: First, service convenience dimensions have been considered without detailing the significance of different dimensions and items for the perception of service convenience. Second, research has yet to explore which moderators affect the relationship between service convenience and customer satisfaction. In addressing these gaps, our study extends and enriches the existing literature.

\section{Research Implications}


Dimensions model. By validating the multidimensional measurement, we reveal the relative importance of service convenience dimensions to the overall perception of service convenience.

Search convenience has the greatest importance. As can be seen by the weights of the indicators (Appendix 1) the orientation within a store and selection of merchandise are particularly significant. Finding prices or locating merchandise on the shelf are relatively less influential. These results emphasize the need to consider such topics as option overload, consumer confusion, assortment complexity, and choice deferral (e.g., Iyengar and Lepper, 2000; Schweizer et al., 2006; Thompson et al., 2005).

Transaction convenience is the next most important dimension. The weights of the indicators reveal the significance of the service experience during payment and checkout, including the ability to reach the cashier quickly and interact with well-trained checkout clerks. Remarkably, however, the availability of different payment options does not influence transaction convenience much.

Decision convenience is almost as important as transaction convenience to the perception of service convenience. Most influential within this dimension is the ease of making a decision about the service provider and determining whether the requested merchandise is available. Customers seem to perceive the most decision convenience when they do not have many alternatives.

Access and after-sales convenience are less important. The minimal importance of access convenience is especially noteworthy, given that research has long cited location as the most important determinant of differentiation and success (Ghosh and Craig, 1986). Perhaps increased consumer mobility forces service providers to differentiate themselves by mitigating option overload and the burden of choosing for their shoppers. Similarly, studies have found that 
aspects other than location affect retail patronage (e.g., Pan and Zinkhan, 2006); for example, Seiders et al. (2000) note the significance of option overload in their finding that many consumers consider large malls inefficient, because they cannot locate their desired stores or product category. Finally, the relatively weak importance of after-sales convenience might reflect the product category and confirm the context-specific nature of service convenience (Jiang et al., 2013). Exchanging products and enforcing guarantees might be less relevant for short-lived products like consumer packaged goods.

Moderator model. The results of our study support the foundational assumption that service convenience is a promising means to enhance customer satisfaction. By reducing the perceived time and effort required to complete the shopping process, companies can enhance satisfaction, a key driver of profitability (Cooil et al., 2007; Homburg et al., 2005).

Furthermore, we have investigated the moderating effects of psychographic and sociodemographic customer characteristics. The link between service convenience and customer satisfaction is positively moderated by time pressure and income, because opportunity costs are higher for consumers who experience more time pressure and earn higher incomes. These consumers value their time more, and thus are even more satisfied when a provider saves them time and effort (Marmorstein and Grewal, 1992).

This relationship also suffers negative moderating effects, such as those exerted by shopping enjoyment and household size. Consumers with high shopping enjoyment are willing to spend time and effort to shop (Reynolds and Beatty, 1999), and larger households can be more flexible in allocating shopping tasks to different members (Gross, 1987). Thus, smaller households and consumers with low shopping enjoyment exhibit greater appreciation when service providers minimize the time and effort required for shopping. 
In keeping with the prior literature, we predicted that older people would have more time for shopping. Thus they would value savings of time and effort less than younger consumers (Ailawadi et al., 2001; East et al., 1998). Our study did not confirm this moderating effect of age, however, which may indicate that the notion of "an older generation" with different demand patterns from younger consumers is inaccurate. First, chronological age seems less important for consumer behavior than perceived age. And second, aging should be better differentiated in the research, perhaps in terms of biological, psychological, and social aging (Mathur and Moschis, 2005). Finally, a growing proportion of older consumers feels "cognitively young." They engage in many leisure activities and may have less time available for shopping (Szmigin and Carrigan, 2001).

\section{Managerial Implications}

Against this backdrop, our study helps service providers understand how to increase service convenience and thus enhance customer satisfaction to drive profitability (Cooil et al., 2007; Homburg et al., 2005). Our research identifies the extent to which each dimension contributes to the overall perceptions of service convenience and offers guidance for prioritizing resources in enhancing service convenience. In addition, our consideration of the moderating effects of customer characteristics on the relationship between service convenience and customer satisfaction provides new details about which customers are likely to value service convenience most.

Our results highlight the importance of an optimized rather than maximized assortment, because search convenience has the greatest impact on overall perceptions of service convenience. Service providers therefore need to emphasize assortment management and address such problems as overwhelming product features (Thompson et al., 2005), consumer confusion 
in the face of wide assortments (Schweizer et al., 2006), and choice deferral (Iyengar and Lepper, 2000). Yet rather than releasing customers from the burden of choice, some providers seem to think instead that maximizing the assortment is a best practice to satisfy customer needs.

Key suppliers could play an important role in optimizing assortments, because products, packaging, and presentation all should aim to enhance search convenience. Customers also value an efficient store layout, and they need support from sales personnel who can provide adequate information quickly. Consumption decisions can be complex, as Berry et al. (2002) acknowledge, and fuel increased demand for such services as personal shopping, concierge agencies, or internet comparison sites. The emergence of these service providers confirms the growing importance of search convenience. The enhancement of in-store convenience should start with improved search convenience.

Furthermore, service providers must realize the importance of the service encounter at checkout (transaction convenience). They should expend the effort to train checkout clerks and minimize the time needed to reach a cashier. The implications of the decision for a service provider (decision convenience) are also crucial, especially in terms of the ease of making this decision and the availability of the desired merchandise. Service providers therefore should provide information through their web sites, advertisements, catalogs, hotlines, and so forth to enable consumers to make decisions about both the service provider and its assortment prior to visiting. For example, on the IKEA web site, customers can check whether a product is in stock in a specific store, allowing them to avoid the inconvenience of visiting the store without being able to purchase particular items.

Service providers can significantly enhance customer satisfaction by sparing their customers time and effort, especially for those customers whose psychographic and sociodemographic 
characteristics indicate that they prioritize service convenience. For example, the greater impact of service convenience on customer satisfaction for those under high time pressure who experience low shopping enjoyment implies that our results are particularly important in industries for which economic shopping is common, such as grocery shopping (Kaltcheva and Weitz, 2006). Selected grocery retailers like Tesco have implemented diverse approaches to address this customer segment by offering different opportunities to combine online and physical grocery shopping: For example, customers save time and effort by being able to save their shopping lists to their online customer accounts for future use. As a result, customers are able to place their order within seconds. Retailers also offer different delivery methods for merchandise: delivery to home or work addresses, or the opportunity for customers to pick up the merchandise either directly at the store or at special $24 / 7$ pick-up stations. Furthermore, the moderating effects of income and household size suggest service providers should adapt their quality and packaging to appeal to smaller households. Yet differentiating the degree of convenience offered on the basis of customers' age is not effective. To allocate their service-related resources optimally, service providers must consider how service convenience affects the satisfaction of various customer segments. The customer group affected most includes small, high-income households in all age groups that are pressed for time and do not enjoy shopping. For retailers, this segment is very valuable and therefore justifies additional attention and further effort. To increase satisfaction within this particular segment, retailers should concentrate on the three most important convenience dimensions (search, transaction, and decision convenience) and develop more tools and special offers. For example, Amazon offers selected products like baby diapers as discounted subscriptions. During ordering, customers choose their favorite delivery interval and 
get their deliveries accordingly. This offer could be expanded to a whole weekend shopping basket: Once ordered, it could be delivered regularly at the most convenient time.

\section{LIMITATIONS AND FURTHER RESEARCH}

To extend our study, additional research efforts should focus on other factors, like involvement or price sensitivity, that may moderate the relationship between service convenience and customer satisfaction. For example, price-sensitive consumers appear more likely to spend time and effort to find the lowest priced products (Marmorstein and Grewal, 1992), and highly involved consumers spend more time and effort in the product selection process (Brown and McEnally, 1992).

Although our focus is the link between service convenience and customer satisfaction, other literature also indicates that service convenience enhances customer loyalty (Pan and Zinkhan, 2006) and affects willingness to pay (Berry et al., 2002). Therefore, further research should investigate the influence of service convenience on these or other outcome variables.

Our research reveals that search convenience has the greatest impact on perceptions of overall convenience, far surpassing access convenience. These results suggest directions of further research. First, we encourage research into what creates an overall satisfying or convenient transaction. Second, conventional wisdom, such as the claim that location is the most or even only important factor in competition, must be challenged. Third, we show that the link between service convenience and satisfaction is influenced by moderators; the influence of various dimensions on overall service convenience might likewise be moderated by certain factors or conditions.

Our study of service convenience focuses on grocery and packaged goods retailing. Because service convenience is highly context specific (Jiang et al., 2013), our results might not 
generalize to other, possibly more hedonic contexts. Our examination of service convenience is also limited to the physical shopping environment, and the results may differ in an online shopping context. Further research should replicate and extend our research across other industries, data collection settings, and into the virtual shopping environment to encourage a more thorough understanding of service convenience. 


\section{REFERENCES}

AC Nielsen. (2015), Deutschland 2015: Handel, Verbraucher, Werbung, AC Nielsen.

Ackerman, D. S. and Gross, B. L. (2003), "So Many Choices, So Little Time: Measuring the Effects of Free Choice and Enjoyment on Perception of Free Time, Time Pressure and Time Deprivation", Advances in Consumer Research, Vol. 30 No. 1, pp. 290-294.

Adams, J. S. (1965), "Inequity in Social Exchange", in: Leonard, B. (Ed.), Advances in Experimental Social Psychology, New York, East Lansing, pp. 267-299.

Ailawadi, K. L., Neslin, S. A. and Gedenk, K. (2001), "Pursuing the Value-Conscious Consumer: Store Brands Versus National Brand Promotions", Journal of Marketing, Vol. 65 No. 1, pp. 71-89.

Andaleeb, S. S. and Basu, A. K. (1994), "Technical Complexity and Consumer Knowledge as Moderators of Service Quality Evaluation in the Automobile Service Industry", Journal of Retailing, Vol. 70 No. 4, pp. 367-381.

Anderson, E. W., Fornell, C. and Lehmann, D. R. (1994), "Customer Satisfaction, Market Share, and Profitability: Findings from Sweden", Journal of Marketing, Vol. 58 No. 3, pp. 53-66.

Anderson, J. C. and Gerbing, D. W. (1991), "Predicting Performance Meausres in a Confirmatory Factor Analysis With a Pretest Assessment of Their Substantive Validities", Journal of Applied Psychology, Vol. 76 No. 5, pp. 732-740.

Armstrong, J. S. and Overton, T. S. (1977), "Estimating Nonresponse Bias in Mail Surveys", Journal of Marketing Research, Vol. 14 No. 3, pp. 396-402.

Babin, B. J., Darden, W. R. and Griffin, M. (1994), "Work and/or Fun: Measuring Hedonic and Utilitarian Shopping Value", Journal of Consumer Research, Vol. 20 No. 4, pp. 644-656.

Beatty, S. E. and Ferrell, M. E. (1998), "Impulse Buying: Modeling its Precursors", Journal of Retailing, Vol. 74 No. 2, pp. 169-191.

Becker, G. S. (1965), "A Theory of the Allocation of Time", The Economic Journal, Vol. 75 No. 299, pp. 493-517.

Berry, L. L. (1979), "The time-Buying Consumer", Journal of Retailing, Vol. 55 No. 4, pp. 5869.

Berry, L. L. (2016), "Revisiting "big ideas in services marketing" 30 years later", Journal of Services Marketing, Vol. 30 No. 1, pp. 3-6.

Berry, L. L., Seiders, K. and Grewal, D. (2002), "Understanding Service Convenience", Journal of Marketing, Vol. 66 No.3, pp 1-17.

Bollen, K. and Lennox, R. (1991), "Conventional Wisdom on Measurement: A Structural Equation Perspective", Psychological Bulletin, Vol. 110 No. 2, pp. 305-314.

Brown, L. G. and McEnally, M. R. (1992), "Convenience: Definition, Structure, and Application", Journal of Marketing Management, Vol. 2, No. 2, pp. 47-56.

Bruhn, M., Georgi, D. and Hadwich, K. (2008), "Customer Equity Management as Formative Second-Order Construct", Journal of Business Research, Vol. 61 No. 12, pp. 1292-1301.

Candel, M. J. (2001), "Consumers' Convenience Orientation towards Meal preparation: Conceptualization and Measurement", Appetite,Vol. 36, pp. 15-28.

Chin, W. W. (1998), "The Partial Least Squares Approach to Structural Equation Modeling", in Marcoulides, G. A. (Ed.), Modern Methods for Business Research, Mahwah London, Lawrence Erlbaum Association, pp. 295-336.

Chin, W. W. (2001), PLS-Graph User's Guide, Houston.

Chin, W. W., Marcolin, B. and Newsted, P. R. (2003), "A Partial Least Squares Latent Variable Modeling Approach for Measuring Interaction Effects: Results from Monte Carlo Simulation Study and Electronic-Mail Emotion/Adaption Study", Information Systems Research, Vol. 14 No.2, pp. 189-217. 
Cohen, J. (1988), Statistical Power Analysis for the Behavioral Sciences, 2nd ed., Hillsdale, Lawrence Erlbaum Associates.

Colwell, S. R., Aung, M., Kanetkar, V. and Holden, A. L. (2008), "Toward a measure of service convenience: multiple-item scale development and empirical test", Journal of Services Marketing, Vol. 22 No. 2, pp. 160-169.

Coltman, T., Devinney, T. M., Midgley, D. F. and Venaik, S. (2008), "Formative versus Reflective Measurement Models: Two Applications of Formative Measurement", Journal of Business Research, Vol. 61 No. 12, pp. 1250-1262.

Cooil, B., Keiningham, T. L., Aksoy, L. and Hsu, M. (2007), "A Longitudinal Analysis of Customer Satisfaction and Share of Wallet: Investigating the Moderating Effects of Customers Characteristics", Journal of Marketing, Vol. 71 No. 1, pp. 67-83.

Dabholkar, P. A., Shepherd, C. D. and Thorpe, D. I. (1996), "Consumer Evaluations of New Technology Based Self Service Options: An Investigation of Alternative Models of Service Quality", International Journal of Research in Marketing, Vol. 13, pp. 29-51.

Davis, M. M. and Vollmann, T. E. (1990), "A Framework For Relating Waiting Time and Customer Satisfaction in a Service Operation", Journal of Services Marketing, Vol. 4 No. 1, pp. 61-69.

Dawson, S., Bloch, P. H. and Ridgway, N. M. (1990), "Shopping Motives, Emotional States, and Retail Outcomes", Journal of Retailing, Vol. 66 No. 4, pp. 408-427.

Diamantopoulos, A. and Winklhofer, H. (2001), "Index Construction with Formative Indicators: An Alternative to Scale Development", Journal of Marketing Research, Vol. 38 No. 2, pp. 269-277.

Diamantopoulos, A., Riefler, P. and Roth, K. P. (2008), Advancing formative measurement models, Journal of Business Research, Vol. 61, No. 12, pp. 1203-12018.

Dillmann, D.A. (2000), Mail and Internet Surveys: The Tailored Design Method, New York, Wiley.

East, R., Harris, P., Lomax, W., Wilson, G. and Hammond, K. (1998), "Customer Defection from Supermarkets", Advances in Consumer Research, Vol. 25 No. 1, pp. 507-512.

Fornell, C. and Cha, J. (1994), "Partial Least Squares", in Bagozzi, R. P. (Ed.), Advanced Methods of Marketing Research, Oxford, Blackwell Business, pp. 52-78.

Fornell, C. and Larcker, D. (1981), "Evaluating Structural Equation Models with Unobservable Variables and Measurement Error", Journal of Marketing Research, Vol. 18 No. 1, pp. 39-50.

Ghosh, A. and Craig, C. S. (1986), "An Approach to Determining Optimal Locations for New Services", Journal of Marketing Research, Vol. 23 No. 4, pp. 354-362.

Govers, P. C. M. and Schoormans, J. P. L. (2005), "Product Personality and its Influence on Consumer Preference", Journal of Consumer Marketing, Vol. 22 No. 4, pp. 189-197.

Grewal, D., Baker, J., Levy, M. and Voss, G. B. (2003), "The Effects of Wait Expectations and Store Atmosphere Evaluations on Patronage Intentions in Service-Intensive Retail Stores", Journal of Retailing, Vol. 79 No. 4, pp. 259-268.

Gross, B. L. (1987), "Time Scarcity: Interdisciplinary Perspectives and Implications for Consumer Behavior", in Sheth, J. N. and Hirschman, E. C. (Eds.), Research in Consumer Behavior, Greenwich, JAI Press, pp. 1-54.

Hair, J. F., Black, B., Babin, B., Anderson, R. E. and Tatham, R. L. (2006), Multivariate Data Analysis (6th ed.), Upper Saddle River, NJ, Prentice Hall.

Homburg, C., Hoyer, W. D. and Koschate, N. (2005), "Customers' Reactions to Price Increases: Do Customer Satisfaction and Perceived Motive Fairness Matter?", Journal of the Academy of Marketing Science, Vol. 33 No. 1, pp. 36-49. 
Hornik, J. (1982), "Situational Effects on the Consumption of Time", Journal of Marketing, Vol. 46 No. 4, pp. 44-55.

Hulland, J. (1999). "Use of Partial Least Squares (PLS) in Strategic Management Research: A Review of Four Recent Studies", Strategic Management Journal, Vol. 20 No. 2, pp. 195204.

Iyengar, S. S., and Lepper, M. R. (2000), "When Choice is Demotivating: Can One Desire Too Much of a Good Thing?", Journal of Personality and Social Psychology, Vol. 79 No. 6, pp. 995-1006.

Iyer, E. S. (1989), "Unplanned Purchasing: Knowledge of Shopping Environment and Time Pressure", Journal of Retailing, Vol. 65 No. 1, pp. 40-57.

Jarvis, C. B., Mackenzie, S. B., and Podsakoff, P. M. (2003), "A Critical Review of Construct Indicators and Measurement Model Misspecification in Marketing and Consumer Research", Journal of Consumer Research, Vol. 30 No. 3, pp. 199-218.

Jiang, L. (A.), Yang, Z. and Jun, M. (2013), "Measuring consumer perceptions of online shopping convenience", Journal of Service Management, Vol. 24 No. 2, pp. 191-214.

Jones, M. A., Mothersbaugh, D. L. and Beatty, S. E. (2000), "Switching Barriers and Repurchase Intentions in Services", Journal of Retailing, Vol. 76 No. 2, pp. 259.

Kaltcheva, V. D. and Weitz, B. A. (2006), "When Should a Retailer Create an Exciting Store Environment?", Journal of Marketing, Vol. 70 No. 1, pp. 107-118.

Kaura, V., Prasad, C. S. D. and Sharma, S. (2014), "Impact of Service Quality, Service Convenience and Perceived Price Fairness on Customer Satisfaction in Indian Retail Banking Sector", Management and Labour Studies, Vol. 39 No. 2, pp. 127-139.

Kaura, V., Prasad, C. S. D. and Sharma, S. (2015) "Service quality, service convenience, price and fairness, customer loyalty, and the mediating role of customer satisfaction", International Journal of Bank Marketing, Vol. 33 No. 4, pp.404 - 422.

Leclerc, F. and Schmitt, B. H. (1995), "Waiting Time and Decision Making: Is Time Like Money?", Journal of Consumer Research, Vol. 22 No. 1, pp. 110-119.

Lloyd, A. E., Chan, R. Y. K., Yip, L. S.C., and Chan, A. (2014), "Time buying and time saving: effects on service convenience and the shopping experience in the mall", Journal of Services Marketing, Vol. 28 No. 1, pp. 36-49.

Lohmöller, J.-B. (1989), Latent Variable Path Modeling with Partial Least Squares, Heidelberg, Physica.

Luu, N., Hau, L. N., Ngo, L. V., Bucic, T. and Cuong, P. H. (2016), "Outcome versus process value in service delivery", Journal of Services Marketing, Vol. 30 No. 6, pp. 630 - 642.

MacKenzie, S. B., Podsakoff, N. P., and Jarvis, C. B. (2005), "The Problem of Measurement Model Misspecification in Behavioral and Organizational Research and Some Recommended Solutions", Journal of Applied Psychology, Vol. 90 No. 4, pp. 710-730.

Marmorstein, H. and Grewal, D. (1992), "The Value of Time Spent in Price-Comparison Shopping: Survey and Experimental Evidence", Journal of Consumer Research, Vol. 19 No. 1, pp. 52-61.

Mathur, A. and Moschis, G. P. (2005), "Antecedents of Cognitive Age: A Replication and Extension", Psychology \& Marketing, Vol. 22 No. 12, pp. 969-994.

McDonald, W. J. (1994), "Time Use in Shopping: The Role of Personal Characteristics", Journal of Retailing, Vol. 70 No. 4, pp. 345-365.

Moeller, S., Fassnacht, M. and Ettinger, A. (2009), "Retaining Customers with Shopping Convenience", Journal of Relationship Marketing, Vol. 8 No. 4, pp. 313-329.

Okada, E. M. and Hoch, S. J. (2004), "Spending Time versus Spending Money", Journal of Consumer Research, Vol. 31 No. 2, pp. 313-323. 
Olsen, L. L. and Johnson, M. D. (2003), "Service Equity, Satisfaction, and Loyalty: From Transaction-Specific to Cumulative Evaluations", Journal of Service Research, Vol. 5 No. 3, pp. 184-195.

Ostrom, A. L., Parasuraman, A., Bowen, D. E., Patrício, L. and Voss, C.A. (2015), "Service Research Priorities in a Raplidly Changing Context", Journal of Service Research, Vol. 18 No. 2, pp. 127-159.

Pan, Y. and Zinkhan, G. M. (2006), "Determinants of retail patronage: A meta-analytical perspective", Journal of the Academy of Marketing Science, Vol. 82 No. 3, pp. 229-243.

Putrevu, S. and Ratchford, B. T. (1997), "A Model of Search Behavior with an Application to Grocery Shopping", Journal of Retailing, Vol. 73 No. 4, pp. 463-486.

Reynolds, K. E. and Beatty, S. E. (1999), "A Relationship Customer Typology", Journal of Retailing, Vol. 75 No. 4, pp. 509-523.

Schafer, J. L., and Graham, J. W. (2002), "Missing data: our view of the state of the art", Psychological Methods, Vol. 7 No. 2, pp. 147-177.

Scholderer, J. and Grunert, K. G. (2005), "Consumers, food and convenience: The long way from resource constraints to actual consumption patterns", Journal of Economic Psychology, Vol. 26, pp. 105-128.

Schweizer, M., Kotouc, A. J. and Wagner, T. (2006), "Scale development for Consumer Confusion", Advances in Consumer Research, Vol. 33, pp. 184-190.

Seiders, K., Berry, L. and Gresham, L. (2000), "Attention, Retailers! How Convenient Is Your Convenience Strategy?", Sloan Management Review, Vol. 41 No. 3, pp. 79-89.

Seiders, K., Voss, G. B., Godfrey, A. L. and Grewal, D. (2007), "SERVCON: development and validation of a multidimensional service convenience scale", Journal of the Academy of Marketing Science, Vol. 35 No. 1, pp. 144-156.

Seiders, K., Voss, G. B., Grewal, D. and Godfrey, A. L. (2005), "Do Satisfied Customers Buy More? Examining Moderating Influences in a Retailing Context", Journal of Marketing, Vol. 69 No. 4, pp. 26-43.

Szmigin, I. and Carrigan, M. (2001), "Time, Consumption, and the Older Consumer: An Interpretive Study of the Cognitively Young", Psychology and Marketing, Vol. 18 No. 10, pp. 1091-1116.

Tenenhaus, M., Vinzi, V. E., Chatelin, Y.-M. and Lauro, C. (2005), "PLS Path Modelling", Computational Statistics and Data Analysis, Vol. 48 No. 1, pp. 159-205.

Thibaut, J. W., Kelley, H. H. (1959), The Social Psychology of Groups, New York, John Wiley \& Sons.

Thompson, D. V., Hamilton, R. W. and Rust, R. T. (2005), "Feature Fatigue: When Product Capabilities Become Too Much of a Good Thing", Journal of Marketing Research, Vol. 42 No. 4, pp. 431-442.

Tse, D. K. and Wilton, P. C. (1988), "Models of Consumer Satisfaction Formation: An Extension", Journal of Marketing Research, Volume 25 January, pp. 204-212.

Urbany, J. E., Dickson, P. A. and Kalapurakal, R. (1996), "Price Search in the Retail Grocery Market", Journal of Marketing, Vol 60 No. 2, pp. 91-104.

van Kenhove, P. and de Wulf, K. (2000), "Income and Time Pressure: A Person-Situation Grocery Retail Typology", International Review of Retail, Distribution and Consumer Research, Vol 10 No. 2, pp. 149-166.

Voss, G. B., Parasuraman, A. and Grewal, D. (1998), "The Role of Price and Quality Perceptions in Prepurchase and Postpurchase Evaluation of Services", Journal of Marketing, Vol. 62 No. 4, pp. 46-61. 
Williams, T., Slama, M. and Rogers, J. (1985), "Behavioral characteristics of the recreational shopper and implications for retail management", Journal of the Academy of Marketing Science, Vol. 13 No. 3, pp. 307-316.

Wold, H. (1966), "Non-linear Estimation by Iterative Least Squares Procedures", in David, F. W. (Ed.), Research Papers in Statistics, New York, pp. 411-444.

Wold, H. (1985), "Partial Least Squares", in Kotz, S. and Johnson, N. L. (Eds.), Encyclopedia of Statistical Sciences (6.th ed.), New York, Wiley, pp. 581-591. 


\section{Appendix 1: Item descriptions: Formative service convenience construct}

\begin{tabular}{|c|c|c|c|c|c|c|}
\hline Items & $\mathbf{p}_{\mathrm{sa}}$ & $\mathbf{c}_{\mathrm{sv}}$ & Weight & t-Value & VIF & $\operatorname{corr}_{\mathrm{ij}}$ \\
\hline \multicolumn{7}{|l|}{ Decision convenience } \\
\hline I quickly receive information at $\mathrm{XYZ}$ prior to shopping. & .75 & .5 & .118 & $3.571 * *$ & 1.279 & $.322 * *$ \\
\hline Deciding to shop at $\mathrm{XYZ}$ is quick. & .90 & .8 & .346 & $7.872 * *$ & 2.370 & $.527 * *$ \\
\hline Deciding to shop at $\mathrm{XYZ}$ is easy. & .75 & .5 & .416 & $9.103 * *$ & 2.303 & $.547 * *$ \\
\hline $\begin{array}{l}\text { I can quickly determine prior to shopping whether } \mathrm{XYZ} \\
\text { offers what I need. }\end{array}$ & 1 & 1 & .383 & $12.551 * *$ & 1.267 & $.424 * *$ \\
\hline \multicolumn{7}{|l|}{ Access convenience } \\
\hline It is easy to reach $\mathrm{XYZ}$. & 1 & 1 & .183 & $2.706^{* *}$ & 2.276 & $.265^{* *}$ \\
\hline It takes little time to get access to the store of XYZ. & .90 & .80 & .158 & $2.287 * *$ & 2.266 & $.236^{* *}$ \\
\hline $\mathrm{XYZ}$ offers convenient parking facilities. & .90 & .80 & .119 & $1.887^{*}$ & 1.853 & $.310^{* *}$ \\
\hline It is easy to get from the parking space to the store. & 1 & 1 & .388 & $5.617 * *$ & 1.982 & $.391 * *$ \\
\hline $\mathrm{XYZ}$ offers convenient opening hours. & 1 & 1 & .552 & $12.762 * *$ & 1.220 & $.403 * *$ \\
\hline \multicolumn{7}{|l|}{ Search convenience } \\
\hline $\begin{array}{l}\text { XYZ makes orientation in the store easy for me (e.g., } \\
\text { helpful signage). }\end{array}$ & .85 & .70 & .256 & $9.447 * *$ & 2.422 & $.597 * *$ \\
\hline $\begin{array}{l}\text { It does not take much time to go the shelves with the } \\
\text { products I want. }\end{array}$ & 1 & 1 & .196 & $7.147 * *$ & 2.758 & $.606^{* *}$ \\
\hline I can quickly locate the merchandise I want at XYZ. & 1 & 1 & .008 & .215 & 2.948 & $.594 * *$ \\
\hline $\begin{array}{l}\text { The atmosphere (e.g., temperature, music, lighting) in the } \\
\text { salesrooms is sometimes stressful. (r) }\end{array}$ & 1 & 1 & .224 & $9.795 * *$ & 1.122 & $.365^{* *}$ \\
\hline I find it easy to select merchandise at XYZ. & .90 & .80 & .298 & $10.771 * *$ & 1.535 & $.520 * *$ \\
\hline $\begin{array}{l}\text { I can quickly get information at XYZ (e.g., about the } \\
\text { location of merchandise I want). }\end{array}$ & 1 & 1 & .221 & $6.495 * *$ & 2.079 & $.607 * *$ \\
\hline It is easy to find the prices of the merchandise. & 1 & 1 & .190 & $7.399 * *$ & 1.443 & $.451^{* *}$ \\
\hline \multicolumn{7}{|l|}{ Transaction convenience } \\
\hline It does not take much time to go to the cashier. & 1 & 1 & .306 & $8.555^{* *}$ & 1.401 & $.477 * *$ \\
\hline $\begin{array}{l}\text { The atmosphere (e.g., temperature, music, lighting) at the } \\
\text { cashier area is sometimes stressful. (r) }\end{array}$ & 1 & 1 & .298 & $9.766^{* *}$ & 1.108 & $.390 * *$ \\
\hline $\begin{array}{l}\text { I am able to complete my purchases quickly at XYZ (e.g., } \\
\text { short lines). }\end{array}$ & 1 & 1 & .164 & $4.331 * *$ & 1.482 & $.445^{* *}$ \\
\hline XYZ has well-trained checkout clerks. & 1 & 1 & .482 & $14.276^{* *}$ & 1.521 & $.500^{* *}$ \\
\hline $\begin{array}{l}\text { XYZ offers convenient possibilities to pay (e.g., cash } \\
\text { card, credit card). }\end{array}$ & .90 & .80 & .203 & $5.628 * *$ & 1.236 & $.320 * *$ \\
\hline
\end{tabular}




\begin{tabular}{|l|c|c|c|c|c|c|}
\hline $\begin{array}{l}\text { XYZ offers generous exchange policies (e.g., conversion } \\
\text { period, money-back guarantee). }\end{array}$ & 1 & 1 & .264 & $4.174^{* *}$ & 2.765 & $.409^{* *}$ \\
\hline It takes little time to exchange products at XYZ. & .90 & .80 & .312 & $5.589^{* *}$ & 2.036 & $.424^{* *}$ \\
\hline It is easy to take care of returns at XYZ. & .95 & .90 & .088 & $1.374^{*}$ & 3.626 & $.412^{* *}$ \\
\hline XYZ replaces defective products without any problems. & .75 & .65 & .001 & .003 & 3.189 & $.394^{* *}$ \\
\hline $\begin{array}{l}\text { XYZ has well-trained clerks for product exchanges and } \\
\text { returns. }\end{array}$ & .85 & .70 & .484 & $7.427^{* *}$ & 2.271 & $.441^{* *}$ \\
\hline $\begin{array}{l}\text { Notes: }(\mathrm{r})=\text { reversed item; XYZ }=\text { name of the retailer; } \mathrm{p}_{\mathrm{sa}}=\text { proportion of substantive agreement; } \mathrm{c}_{\mathrm{sv}}=\text { substantive validity } \\
\text { coefficient; VIF }=\text { variance inflation factor; corr } \\
<.05 ; * * \text { ij } p<.01 ; \text { coefficients in italics are not significant. }\end{array}$ \\
\hline
\end{tabular}

\section{Appendix 2: Item descriptions of the reflective constructs}

\begin{tabular}{|c|c|c|c|c|c|}
\hline Items & $\begin{array}{l}\text { Stand. } \\
\text { Loadings }\end{array}$ & t-Value & $\begin{array}{l}\text { Cronbach's } \\
\text { Alpha }\end{array}$ & $\begin{array}{c}\text { Factor } \\
\text { Reliability }\end{array}$ & AVE \\
\hline \multicolumn{6}{|l|}{ Service convenience (reflective) } \\
\hline XYZ allows me to do my shopping quickly. & .8754 & $88.54 * *$ & \multirow{4}{*}{.933} & \multirow{4}{*}{.9525} & \multirow{4}{*}{.8338} \\
\hline $\begin{array}{l}\text { Overall XYZ allows me to do my shopping } \\
\text { without any stress. }\end{array}$ & .9209 & $111.05 * *$ & & & \\
\hline $\begin{array}{l}\text { I perceive all things considering shopping } \\
\text { experience at } X Y Z \text { as comfortable. }\end{array}$ & .9205 & $144.40^{* *}$ & & & \\
\hline Shopping at $\mathrm{XYZ}$ is very convenient. & .9346 & $198.78 * *$ & & & \\
\hline \multicolumn{6}{|l|}{ Customer satisfaction (SAT) } \\
\hline Overall I am very satisfied with XYZ. & .923 & $166.634 * *$ & \multirow{3}{*}{.905} & \multirow{3}{*}{.940} & \multirow{3}{*}{.840} \\
\hline $\mathrm{XYZ}$ always fulfills my expectations. & .919 & $122.797 * *$ & & & \\
\hline My experiences with XYZ are very positive. & .908 & $108.630^{* *}$ & & & \\
\hline \multicolumn{6}{|l|}{ Time pressure $(\mathrm{TP})$} \\
\hline When I purchase groceries I am always in hurry. & .905 & $38.839 * *$ & \multirow{3}{*}{.859} & \multirow{3}{*}{.912} & \multirow{3}{*}{.776} \\
\hline I only ever have limited time for grocery shopping. & .820 & $17.100^{* *}$ & & & \\
\hline $\begin{array}{l}\text { When I purchase groceries I feel most of the time } \\
\text { time-pressured. }\end{array}$ & .915 & $50.899 * *$ & & & \\
\hline \multicolumn{6}{|l|}{ Shopping enjoyment (SE) } \\
\hline I think grocery shopping is a chore. (r) & .816 & $38.470 * *$ & \multirow{3}{*}{.727} & \multirow{3}{*}{.844} & \multirow{3}{*}{.643} \\
\hline $\begin{array}{l}\text { I like to finish my shopping as quickly as possible } \\
\text { and get out of the store. (r) }\end{array}$ & .736 & $29.564 * *$ & & & \\
\hline I enjoy grocery shopping. & .849 & $43.218^{* *}$ & & & \\
\hline
\end{tabular}

